PSYCHOLOGIA ROZWOJOWA, $2019 *$ tom 24 , nr 4, s. 23-38

doi:10.4467/20843879PR.19.020.11726

www.ejournals.eu/Psychologia-Rozwojowa

DOROTA SUWALSKA-BARANCEWICZ ID ORCID ORG/0000-0001-6495-9796

ALICJA MALINA ID ORCID 0000-0001-8866-5493

\author{
Zakład Psychologii Społecznej i Badań nad Młodzieżą \\ Uniwersytet Kazimierza Wielkiego, Bydgoszcz \\ Department of Social Psychology and Studies on Adolescents \\ Institute of Psychology, Kazimierz Wielki University in Bydgoszcz \\ dsbarancewicz@ukw.edu.pl; alamalina@gmail.com
}

\title{
Jakość więzi z dzieckiem i prężność matek a ich satysfakcja z życia
}

\section{Resilience, Maternal Bond Quality and the Mother's Life Satisfaction}

\begin{abstract}
The presented research analyses the relationship between resilience, the mother-child bond, and the life satisfaction of young mothers. The assumption regarding the importance of resilience in taking on parental responsibilities was drawn from studies indicating the protective effect of individual resilience in difficult situations. It was assumed that resilience could work as a buffer between the mother-child bond and maternal life satisfaction. For measuring resilience the Lifespan Individual Resilience Scale in the adaptation of Malina, Pooley, Harms (2016) was used. The Mother-Child Bond Tool in the Bielawska-Batorowicz adaptation (2006) was used to assess the quality of relationship with the child. Satisfaction with life was evaluated using the Satisfaction with Life Scale in the adaptation of Juczyński (2009). The study participants were 340 women in early adulthood who have at least one child under the age of 2 . Research indicates that resilience as well as particular aspects of the mother-child bond are important for maternal life satisfaction. It was also established that resilience plays a mediative role between the mother -child bond and the life satisfaction of the mother.
\end{abstract}

Keywords: motherhood, resilience, mother-child bond, life satisfaction

Słowa kluczowe: macierzyństwo, prężność, więź z dzieckiem, satysfakcja z życia

\section{WPROWADZENIE}

Współcześnie człowiek doświadcza przeciążenia pełnionymi funkcjami, co może być źródłem napięć i stresu. Pojawienie się w rodzinie dziecka - nowego, wymagającego uczestnika wszystkich interakcji może dodatkowo przysparzać rodzinie, poza pozytywnymi emocjami, trudności adaptacyjnych. Niezależnie od przebiegu ciąży i porodu przyjście na świat dziecka zawsze jest źródłem silnych przeżyć, które mogą dodatnio lub ujemnie wpływać na satysfakcję z życia pary małżeńskiej. Autorki zwracają uwagę, że wysoki poziom satysfakcji z małżeństwa odczuwany w początkowych jego fazach bardzo szybko ulega silnemu obniżeniu. Tendencja ta często jest wiązana właśnie z przyjściem na świat dzieci. Małżonkowie (a w szczególności żony), pochłonięci opieką nad niemowlęciem, mają mniej czasu dla siebie wzajemnie oraz dla samych siebie. Obniżenie satysfakcji z małżeństwa w tym okresie można również tłumaczyć pogorszeniem się sytuacji finansowej rodziny. Kiedy rodzinie 
uda się już poradzić sobie z tymi trudnościami, poziom satysfakcji z małżeństwa wraca zwykle do stanu wyjściowego. Spadek poczucia satysfakcji z życia małżonków zwykle odnotowuje się do momentu, kiedy dzieci zaczynają wchodzić w wiek dorastania (Braun-Gałkowska, 1992; Wojciszke 2004). Jednocześnie badania wskazują, że rodzinę uznaje się za najważniejsze źródło satysfakcji, a wartości afiliacyjne w dalszym ciągu są wysoko cenione przez współczesne rodziny (Malina, 2014; Szafraniec, 2011). Można zatem przypuszczać, że dla młodych rodziców istotnym czynnikiem decydującym o satysfakcji z życia jest jakość więzi z dzieckiem. Zważywszy na osłabienie więzi z partnerem i jej znaczenia dla satysfakcji z życia więź z dzieckiem nabiera szczególnej doniosłości dla młodych kobiet, dla których rola matki stanowi bardzo istotny element tożsamości społecznej. Badania podkreślają znaczenie korzyści wychowania dzieci dla rozwoju indywidualnego rodziców. Należy także zwrócić uwagę na wymagania, jakie stawia przed człowiekiem rodzicielstwo. Dla przykładu Nomaguchi (2012) zanalizował związek między wiekiem dzieci - próba rodziców dzieci w wielu 0-22 lat $(\mathrm{N}=6228)-$ a rodzicielskim dobrostanem psychicznym, z uwzględnieniem mediacyjnej roli zadowolenia z relacji rodzicdziecko. Wyniki wskazują, że rodzice, których najstarsze dziecko ma mniej niż 5 lat, wykazują większą satysfakcję ze związku z dziećmi, wyższą samoocenę, wyższe poczucie własnej skuteczności i mniejszą depresyjność niż rodzice, których najstarsze dziecko jest w wieku szkolnym lub nastoletnim.

Dotychczasowe badania empirycznie dotyczące dobrostanu psychicznego rodziców pozwalają na wyciagnięcie następujących wniosków. Po pierwsze, rodzicielstwo jest zarówno uciążliwe, jak i satysfakcjonujące (Bird, 1997). Po drugie, między rodzicami mogą istnieć znaczące różnice indywidualne w zakresie, w jakim rodzicielstwo jest dla nich uciążliwe lub wynagradzające, co w dużej mierze kształtuje kontekst społeczny, w którym funkcjonują (Evenson, Simon, 2005; Umberson, Pudrovska, Reczek, 2010). Czynnikiem wspomagającym rodziców może się okazać ich prężność.
Wobec licznych trudności, jakich doświadcza współczesny człowiek, ważna dla jakości funkcjonowania w każdej dziedzinie, także w sferze rodzicielstwa, jest umiejętność radzenia sobie z obciążeniami, a także szybkiego odzyskiwania równowagi w sytuacji kryzysu. Badania Ramony Mercer i Sandry Ferketisch (1990) wskazują, iż w kształtowaniu się więzi emocjonalnej między dzieckiem a rodzicami ważną rolę odgrywa jakość relacji współmałżonków, poczucie własnej wartości obojga rodziców oraz wsparcie, które otrzymują od innych. Trudne sytuacje związane z przebiegiem ciąży oraz niekorzystne stany emocjonalne mogą również osłabiać jakość przywiązania między rodzicem a dzieckiem (Mercer, Ferketisch, May, DeJoseph, Sollid, 1988).

Prężność definiuje się jako proces skutecznego przezwyciężania trudnych zdarzeń pod wpływem transakcji jednostki i systemu, w obrębie którego funkcjonuje. Prężność jest związana ze zdolnością do pozyskiwania i budowania zasobów sprzyjających zdrowiu oraz z możliwością zabezpieczenia tych zasobów przez środowisko rodzinne i otoczenie społeczne w kontekście doświadczania stresu, trudności i kryzysów. Jako synonim zaradności życiowej prężność stanowi jeden $\mathrm{z}$ istotnych czynników wspomagających człowieka w zmaganiu się z trudnościami. Powinna być ona rozpatrywana jako ciągle rozwijana i udoskonalana zdolność do realizacji zadań, często w trudnych i stresujących warunkach życia (Charney, 2004; Connor, 2006; Hjemdal, 2007; Pooley, Cohen, O’Connor, 2010).

Liczne badania wskazują na znaczenie prężności w dokonywaniu wyboru konstruktywnych strategii radzenia sobie. Prężność sprzyja podejmowaniu przystosowawczych strategii i zmniejsza skłonność do korzystania ze strategii nieadaptacyjnych. Jednostki odznaczające się prężnością skuteczniej radzą sobie ze stresem. Skuteczność ta wiąże się między innymi z częstszym wykorzystywaniem $\mathrm{w}$ tym procesie strategii powiązanych $\mathrm{z}$ emocjami pozytywnymi, takich jak koncentracja na zadaniu, pozytywne przewartościowanie czy nadawanie wydarzeniom pozytywnego znaczenia. Skutkuje to bardziej efektywnym 
radzeniem sobie. Osoby charakteryzujące się wyższym nasileniem prężności w większym stopniu angażują się w relacje $\mathrm{z}$ innymi ludźmi, w tym z najbliższą rodziną (Connor, 2006). Badania wskazują także na znaczenie prężności w tworzeniu i utrzymywaniu satysfakcjonujących więzi społecznych (Heszen, Sęk, 2007; por. Ogińska-Bulik, Juczyński, 2008). Jak wynika z dotychczasowych badań, prężność stanowi także jeden z czynników oddziałujących na poziom ogólnego zadowolenia z życia (Ogińska-Bulik, 2014). Osoby odznaczające się wysokim poziomem prężności są bardziej pozytywnie nastawione do życia i charakteryzują się stabilnością emocjonalną, co sprzyja tworzeniu więzi społecznych. Prężność psychiczna jest także czynnikiem ułatwiającym mobilizację w sytuacjach kryzysowych. Wysoki poziom prężności sprzyja również tolerancji negatywnych emocji i niepowodzeń, co w sytuacjach kryzysowych może zabezpieczać rodziców przed spadkiem odczuwanej satysfakcji (Simer, 2006).

Znaczenie prężności, jako czynnika chroniącego i zabezpieczającego dobrostan rodziców, było wielokrotnie podejmowane w badaniach. Autorzy jednak zwykli koncentrować się na kryzysach, które znacząco zaburzają stan równowagi rodziny. Wskazywano na przykład na znaczenie prężności w radzeniu sobie $\mathrm{z}$ chorobą nowotworową u dzieci i ich matek (Shin, Lee, 2008). Badania w populacji koreańskich matek dzieci z chorobą nowotworową wykazały, że poziom prężności matki i dziecka są ze sobą związane i oddziałują na jakość funkcjonowania obojga. Podejmowano także problem znaczenia prężności dla satysfakcji z życia matek dzieci ze schorzeniami przewlekłymi (Horton, Wallander, 2001). Wskazywano też na znaczenie prężności dla jakości więzi z dzieckiem i satysfakcji z życia wśród nieletnich matek (Hess, Papas, Black, 2002). Brakuje jednak w literaturze danych dotyczących związku prężnościzmiennej powiązanej z pomyślnym radzeniem sobie - z jakością więzi z dzieckiem i, co za tym idzie, z satysfakcją z życia w grupie matek zdrowych dzieci.

Wydaje się, że współczesny świat wymusza na rodzicach dysponowanie umiejętnościami szybkiego powrotu do stanu równowagi, gdyż rodzicielstwo samo w sobie stanowi dziś pewnego rodzaju kryzys. Dotychczasowe nieliczne badania w tej dziedzinie, prowadzone na polskim gruncie, wskazują na znaczenie prężności dla kształtowania się więzi z nienarodzonym dzieckiem. Będzie ona miała jednak różne znaczenie w zależności od tego, czy jest to pierwsze czy kolejne dziecko pary, a także czy doświadczyli oni problemów prokreacyjnych i jak przebiegała ciąża (Pawlicka, Chrzan-Dętkoś, Lutkiewicz, 2013). Problem zestawiania więzi z dzieckiem - jako czynnika nagradzającego rodzica - i satysfakcji z życia, która często mocno łączy się z relacją z dzieckiem, wymaga dalszej eksploracji. Autorki pragną zwrócić szczególną uwagę na mediującą rolę prężności, która, naszym zdaniem, może w znacznym stopniu facylitować radzenie sobie z trudnościami w opiece i wychowaniu dziecka, a co za tym idzie - w tworzeniu się silnej i stabilnej więzi $\mathrm{z}$ potomstwem.

\section{PROBLEM I CEL BADAŃ}

W realizowanym badaniu podjęto problem znaczenia prężności młodych matek dla jakości więzi z dzieckiem oraz odczuwanej przez nie satysfakcji z życia. Celem badania było przeanalizowanie, czy prężność wiąże się z poszczególnymi wymiarami więzi z dzieckiem, czyli z jakością więzi, brakiem wrogości wobec dziecka, przyjemnością w kontakcie $\mathrm{z}$ dzieckiem oraz satysfakcją z życia młodych matek. Poziom prężności młodych matek uznano za czynnik pośredniczący pomiędzy jakością ich więzi z dzieckiem a odczuwaną przez nie satysfakcją z życia. Przeprowadzenie odpowiednich analiz statystycznych umożliwiło wnioskowanie o wyznacznikach satysfakcji z życia matek. Na podstawie literatury przedmiotu sformułowano następujące hipotezy badawcze:

1. Poziom prężności istotnie wiąże się zarówno $\mathrm{z}$ wymiarami więzi matki $\mathrm{z}$ dzieckiem (jakością więzi, brakiem wrogości wobec dziecka, przyjemnością w kontakcie z dzieckiem), jak i z satysfakcją z życia matek: im wyższy poziom prężności, tym wyższa jest 
jakość więzi matki z dzieckiem oraz wyższy poziom jej satysfakcji z życia.

2. Prężność jest mediatorem pomiędzy jakością więzi matki z dzieckiem a odczuwaną przez nią satysfakcją z życia: im wyższa jakość więzi matki z dzieckiem, tym wyższy poziom prężności, a w rezultacie wyższa satysfakcja z życia.

\section{BADANE ZMIENNE I SPOSÓB ICH POMIARU}

$\mathrm{Na}$ potrzeby realizacji badań uwzględniono następujące zmienne badawcze:

Zmienna zależna: Zmienną zależną $\mathrm{w}$ realizowanych badaniach była satysfakcja z życia rozumiana jako subiektywna ocena zadowolenia z własnej sytuacji życiowej poprzez porównanie jej z ustalonymi przez siebie standardami. Jeśli wynik takiego odniesienia jest zadowalający, to w rezultacie jest odczuwana satysfakcja. Do pomiaru satysfakcji z życia posłużyła Skala Satysfakcji z Życia (SWLS) autorstwa Eda Dienera i współpracowników (1985) w polskiej adaptacji Zygfryda Juczyńskiego (2009). Składa się ona z pięciu twierdzeń, do których badany się ustosunkowuje, oceniając, w jakim stopniu każde z nich odnosi się do jego dotychczasowego życia. Odpowiedzi są umieszczane na siedmiostopniowej skali od 1 - „zdecydowanie się nie zgadzam”, do 7 - „całkowicie się zgadzam”. Zakres wyników mieści się w granicach 5-35 punktów. Wyższy wynik świadczy o silniejszym poczuciu satysfakcji z życia. Rzetelność metody ustalona z użyciem współczynnika alfa Cronbacha jest zadowalająca i wynosi .81. Wskaźnik stabilności czasowej skali jest satysfakcjonujący i wynosi .86.

Zmienne niezależne: Zmiennymi niezależnymi w realizowanych badaniach były: jakość więzi z małym dzieckiem oraz prężność.

Koncepcja więzi z nienarodzonym dzieckiem Johna T. Condona (1993) - określana mianem hierarchicznego modelu przywiązania prenatalnego - zakłada, że przywiązanie jest uczuciem miłości do nienarodzonego dziecka. Autor operacjonalizuje uczucie miłości do dziecka za pomocą pięciu dyspozycji zwanych również potrzebami. Zdaniem Condona odczuwanie miłości oznacza chęć poznania obiektu swoich uczuć, nawiązania kontaktu z nim, unikania rozłąki, dbałości o niego i chronienia go, a także zaspokajania jego potrzeb. Dyspozycje te mają swój wyraz w zachowaniach koncentrujących się na poszukiwaniu informacji o obiekcie uczuć, stworzeniu długotrwałego bliskiego kontaktu, chronieniu, sprawianiu przyjemności, wrażliwości w zaspokajaniu potrzeb bez oczekiwania wzajemności. Autor metody uważa, że wymienione przejawy miłości można odnieść do emocjonalnej więzi z dzieckiem również po jego pojawieniu się na świecie, co umożliwia długofalowe obserwowanie więzi z dzieckiem (Bielawska-Batorowicz, 2006). Metoda przeznaczona do pomiaru więzi matki/ojca z dzieckiem składa się 19 stwierdzeń, do których osoba badana się ustosunkowuje, wybierając jedną odpowiedź z dwóch, trzech, czterech lub pięciu możliwości. Narzędzie zawiera trzy wymiary: jakość więzi (np. „Kiedy nawiązuję kontakt dzieckiem. czuję się: [ ] bardzo niekompetentna i niepewna siebie; [ ] niekompetentna i niepewna siebie; [ ] dość kompetentna i pewna siebie; [ ] bardzo kompetentna i pewna siebie"), brak wrogości wobec dziecka (np. „Biorąc pod uwagę rzeczy, z których musieliśmy zrezygnować ze względu na dziecko: [ ] bardzo żałuję, że musieliśmy z nich zrezygnować; [ ] raczej żałuję, że musieliśmy z nich zrezygnować; [ ] czasami żałuję, że musieliśmy z nich zrezygnować; [ ] wcale nie żałuję") oraz przyjemność w kontakcie z dzieckiem (np. „Kiedy jestem z dzieckiem: [ ] zwykle staram się przedłużyć czas z nim spędzany; [ ] zwykle staram się skrócić czas z nim spędzany"). Niskie wyniki świadczą o problematycznej więzi rodzica z dzieckiem. Im wyższy wynik, tym wyższe nasilenie emocjonalnej więzi matki/ojca z dzieckiem (Condon, Corkindale, 1998). Rzetelność metody jest satysfakcjonująca. Współczynnik alfa Cronbacha wynosi .95.

Prężność jest ujmowana jako konstrukt odpowiedzialny za ,potencjał do prezentowania zaradności przez użycie dostępnych zasobów wewnętrznych i zewnętrznych w odpowiedzi 
na zmiany kontekstu i zmiany rozwojowe" (Pooley, Cohen, 2010, s. 34). Skala Osobistej Adaptacyjności - LIRS(pl) stanowi narzędzie samoopisowe składające się z 12 twierdzeń przyporządkowanych do trzech skal odpowiadających trzem składowym prężności - zasobom osobistym („Osiagam to, co postanowiłem/am zrobić”), wsparciu ze strony rodziny (,Moja rodzina jest dla mnie źródłem siły”) i ze strony rówieśników („Czuję silną więź z przyjaciółmi”). Badany ustosunkowuje się do twierdzeń na siedmiostopniowej skali (1 - zdecydowanie się nie zgadzam, 7 - zdecydowanie się zgadzam). Badanie z użyciem narzędzia pozwala na uzyskanie zarówno ogólnego wyniku w zakresie prężności, jak i wyniku dla poszczególnych podskal.

Rzetelność poszczególnych podskal narzędzia mierzona współczynnikiem alfa Cronbacha jest satysfakcjonująca i wynosi dla zasobów osobistych (.85), dla wsparcia ze strony rodziny (.93) oraz dla wsparcia rówieśniczego (.94). Stabilność czasowa wynosi odpowiednio dla skal: zasoby osobiste -.84 , wsparcie ze strony rodziny - .93, wsparcie ze strony rówieśników - 90 (Malina, Pooley, Harms, 2016).

\section{CHARAKTERYSTYKA BADANYCH OSÓB}

W badaniu wzięło udział 296 kobiet - matek w okresie wczesnej dorosłości (średnia wieku 30.8; $S D=4.32$ ), które po raz pierwszy zostały matkami w wieku 20-39 lat i mających co najmniej jedno dziecko, które nie ukończyło 24. miesiąca życia (średnia wieku 12.5 miesiąca; $S D=6.34)$. Dla $62 \%$ badanych matek było to pierwsze dziecko, dla $32 \%$ drugie, a dla pozostałej części badanych kobiet (6\%) - trzecie i kolejne. Większość badanych matek miała wykształcenie wyższe $(82.09 \%), 53$ średnie (16.89\%), trzy kobiety natomiast wykształcenie podstawowe (1.01\%). Zdecydowana większość badanych $(66.89 \%)$ pochodziła z dużych miast (powyżej 100 tys. mieszkańców), 20.27\% kobiet mieszkało w mniejszych miastach, najmniej zaś - $12.84 \%$ kobiet na wsi. Prawie $80 \%$ badanych matek to mężatki (79.73\%), panny stanowiły $17.23 \%$ ogółu badanych, rozwiedzionych było wśród badanych kobiet osiem (tabela 1).

\section{PROCEDURA}

Badanie zostało zrealizowane w lipcu i sierpniu 2017 roku drogą internetową poprzez rozesłanie do internautów linku dostępu do formularza elektronicznego. Uczestniczkami badania były osoby udzielające się w zamkniętych grupach poświęconych rodzicielstwu i wychowywaniu dzieci. Badanie online przeprowadzono zgodnie z wytycznymi Międzynarodowej Komisji ds. Testów (International Test Commission, 2005) z uwzględnieniem: 1) dążenia do uwierzytelniania osób wypełniających kwestionariusze, 2) zaznajomienia respondentów z celem, procedurą i zakresem badania oraz 3 ) etycznych zasad bezpieczeństwa i poufności zebranych wyników.

\section{WYNIKI}

W celu weryfikacji hipotez dokonano analizy z wykorzystaniem współczynnika korelacji $r$-Pearsona, analizę regresji wielokrotnej, analizę skupień oraz analizę wariancji. Analizy statystyczne przeprowadzono w programie statystycznym Statistica 12.0. Statystyki opisowe badanych zmiennych zostały zaprezentowane w tabeli 2.

Zdecydowano się wykorzystać metody parametryczne zgodnie z centralnym twierdzeniem granicznym, w myśl którego stosowanie statystyk nieparametrycznych nie ma uzasadnienia w przypadku dużych zbiorów danych $(n>100)$ upodabniających się rozkładem do rozkładu normalnego. 
Tabela 1. Charakterystyka osób badanych: rozkład liczebności oraz rozkład procentowy zmiennych socjodemograficznych w badanej próbie

\begin{tabular}{|c|c|c|}
\hline Zmienna & Liczba & Procent \\
\hline \multicolumn{3}{|l|}{ Wykształcenie } \\
\hline Podstawowe & 3 & 1.01 \\
\hline Średnie & 53 & 16.89 \\
\hline Wyższe & 243 & 82.09 \\
\hline \multicolumn{3}{|l|}{ Miejsce zamieszkania } \\
\hline Wieś & 38 & 12.84 \\
\hline Miasto do 100 tys. mieszkańców & 60 & 20.27 \\
\hline Miasto 100-500 tys. mieszkańców & 93 & 31.42 \\
\hline Miasto powyżej 500 tys. mieszkańców & 105 & 35.47 \\
\hline \multicolumn{3}{|l|}{ Stan cywilny } \\
\hline Panna & 51 & 17.23 \\
\hline Zamężna & 236 & 79.73 \\
\hline Rozwiedziona & 8 & 2.70 \\
\hline Wdowa & 1 & 0.34 \\
\hline \multicolumn{3}{|l|}{ Forma związku } \\
\hline Chodzę na randki z różnymi osobami & 1 & 0.34 \\
\hline Jestem w stałym związku (spotykam się z jedną osobą) & 1 & 0.34 \\
\hline Jestem w stałym związku i mieszkam z partnerem & 36 & 12.16 \\
\hline Jestem w okresie narzeczeństwa, ale nie mieszkam z narzeczonym & 1 & 0.34 \\
\hline Jestem w okresie narzeczeństwa i mieszkam z narzeczonym & 20 & 6.76 \\
\hline Jestem zamężna & 232 & 78.38 \\
\hline Jestem w separacji, ale mieszkam z mężem & 2 & 0.68 \\
\hline Jestem samotna & 3 & 1.01 \\
\hline \multicolumn{3}{|l|}{ Sytuacja mieszkaniowa } \\
\hline Posiadamy własne mieszkanie i tylko my w nim mieszkamy & 198 & 66.89 \\
\hline Wynajmujemy samodzielne mieszkanie & 55 & 18.58 \\
\hline Wynajmujemy mieszkanie ze znajomymi & 1 & 0.34 \\
\hline Mieszkamy z moimi rodzicami & 23 & 7.77 \\
\hline Mieszkamy z teściami & 9 & 3.04 \\
\hline Mieszkamy z jednym z moich rodziców & 3 & 1.01 \\
\hline Mieszkamy z jednym z teściów & 4 & 1.35 \\
\hline Mieszkamy z rodzeństwem moim lub rodzeństwem partnera & 3 & 1.01 \\
\hline
\end{tabular}

Źródło: opracowanie własne. 
Tabela 2. Rozkład wyników (statystyki opisowe) badanych zmiennych

\begin{tabular}{|l|c|c|c|c|c|c|}
\hline \multirow{2}{*}{ Zmienna } & \multicolumn{6}{c|}{ Statystyki opisowe } \\
\cline { 2 - 7 } & $\mathrm{N}$ & Średnia & Mediana & Minimum & Maksimum & $\begin{array}{c}\text { Odchylenie } \\
\text { standardowe }\end{array}$ \\
\hline Zasoby osobiste & 296 & 22.48 & 23.00 & 8.00 & 28.00 & 3.93 \\
\hline Rodzina & 296 & 23.99 & 25.00 & 4.00 & 28.00 & 4.80 \\
\hline Przyjaciele & 296 & 18.60 & 19.00 & 4.00 & 28.00 & 6.55 \\
\hline Prężność ogółem & 296 & 65.07 & 67.00 & 23.00 & 84.00 & 11.90 \\
\hline Jakość więzi z dzieckiem & 296 & 38.35 & 39.00 & 22.00 & 45.00 & 4.72 \\
\hline $\begin{array}{l}\text { Brak wrogości względem } \\
\text { dziecka }\end{array}$ & 296 & 15.76 & 16.00 & 7.00 & 23.00 & 2.79 \\
\hline $\begin{array}{l}\text { Przyjemność w kontak- } \\
\text { cie z dzieckiem }\end{array}$ & 296 & 20.33 & 22.00 & 9.00 & 25.00 & 4.16 \\
\hline Satysfakcja z życia & 296 & 23.58 & 24.00 & 5.00 & 35.00 & 6.08 \\
\hline
\end{tabular}

Źródło: opracowanie własne.

\section{RELACJA MIĘDZY WYMIARAMI PRĘŻNOŚCI MATEK \\ A ICH SATYSFAKCJĄ Z ŻYCIA}

W pierwszej kolejności przystąpiono do analizy związku między poszczególnymi wymiarami prężności matek (zasoby osobiste, rodzina, przyjaciele, prężność ogółem) a wymiarami ich satysfakcji z życia. W tym celu użyto współczynnika korelacji $r$-Pearsona.
Zachodzą istotne związki między poszczególnymi wymiarami prężności matek a ich satysfakcją z życia. Im wyższy był poziom wsparcia udzielanego matce przez rodzinę $(r=.50 ; p<.001)$ i przyjaciół $(r=28 ; p<.001)$, a także im więcej zasobów do zmagania się $\mathrm{z}$ trudnościami miała matka $(r=.63 ; p<.001)$, tym bardziej była usatysfakcjonowana z życia (tabela 3).

Tabela 3. Relacja między wymiarami prężności matek a ich satysfakcją z życia

\begin{tabular}{|l|c|}
\hline \multirow{2}{*}{ Zmienna } & Współczynnik korelacji $r$-Pearsona, $p<.05000, N=296$ \\
\cline { 2 - 2 } & Satysfakcja z życia \\
\hline Zasoby osobiste & .63 \\
\hline & $p<.001$ \\
\hline Rodzina & .50 \\
\hline Przyjaciele & $p<.001$ \\
\hline & .28 \\
\hline Prężność ogółem & $p<.001$ \\
\hline & .57 \\
\hline
\end{tabular}

Źródło: opracowane własne. 
RELACJA MIĘDZY WYMIARAMI JAKOŚCI WIĘZI MATEK Z DZIECKIEM A ICH SATYSFAKCJĄ Z ŻYCIA

W dalszej kolejności przystąpiono do określenia związku między poszczególnymi wymiarami więzi matek z dziećmi a satysfakcją z życia matek. W tym celu również posłużono się współczynnikiem korelacji $r$-Pearsona. Wyniki wskazały na istotny związek między jakością więzi $(r=.043 ; p<.001)$, brakiem wrogości wobec dziecka $(r=.41 ; p<.001)$ i przyjemnością w kontakcie z dzieckiem $(r=.23 ; p<.001)$ a matczyną satysfakcją z życia. Im wyższa była jakość więzi z dzieckiem, im mniej wrogości wobec dziecka oraz im większa przyjemność w kontakcie z dzieckiem, tym wyższy był poziom satysfakcji z życia młodych matek (tabela 4).

\section{RELACJA MIĘDZY WYMIARAMI PRĘŻNOŚCI MATEK A WYMIARAMI ICH WIĘZI Z DZIECKIEM}

W kolejnym etapie analiz przystapiono do określenia związku między poszczególnymi wymiarami prężności matek (zasoby osobiste, rodzina, przyjaciele, prężność ogółem) a wymiarami ich więzi z dzieckiem (jakość więzi, brak wrogości wobec dziecka, przyjemność w kontakcie

Tabela 4. Relacja między wymiarami jakości więzi matek z dzieckiem a ich satysfakcją z życia

\begin{tabular}{|l|c|}
\hline \multirow{2}{*}{ Zmienna } & Współczynnik korelacji $r$-Pearsona, $p<.05000, N=296$ \\
\cline { 2 - 3 } & Satysfakcja z życia \\
\hline Jakość więzi & .43 \\
\hline & $p<.001$ \\
\hline Brak wrogości względem dziecka & .41 \\
\hline & $p<.001$ \\
\hline Przyjemność w kontakcie z dzieckiem & .23 \\
\hline & $p<.001$ \\
\hline
\end{tabular}

Źródło: opracowanie własne.

Tabela 5. Relacja między wymiarami prężności matek a wymiarami ich więzi z dzieckiem

\begin{tabular}{|l|c|c|c|}
\hline \multirow{2}{*}{ Zmienna } & \multicolumn{3}{|c|}{ Współczynnik korelacji $r$-Pearsona, $p<.050, N=296$} \\
\cline { 2 - 4 } & Jakość więzi z dzieckiem & $\begin{array}{c}\text { Brak wrogości } \\
\text { względem dziecka }\end{array}$ & $\begin{array}{c}\text { Przyjemność w kontakcie } \\
\text { z dzieckiem }\end{array}$ \\
\hline Zasoby osobiste & .43 & .35 & .31 \\
\hline & $p<.001$ & $p<.001$ & $p<.001$ \\
\hline Rodzina & .43 & .32 & .36 \\
\hline Przyjaciele & $p<.001$ & $p<.001$ & $p<.001$ \\
\hline & .35 & .28 & .25 \\
\hline Prężność ogółem & $p<.001$ & $p<.001$ & $p<.001$ \\
\hline & .51 & .40 & $p<$ \\
\hline
\end{tabular}

Źródło: opracowanie własne. 
z dzieckiem). W tym celu użyto współczynnika korelacji $r$-Pearsona.

Analiza korelacji dowiodła występowania istotnych związków między poszczególnymi wymiarami prężności matek a jakością więzi z dzieckiem. Im wyższy był poziom poszczególnych wymiarów prężności, tym wyższy był poziom poszczególnych wymiarów więzi, czyli wraz ze wzrostem prężności wzrastała również jakość więzi matki z dzieckiem (tabela 5).

\section{PRĘŻNOŚĆ JAKO MEDIATOR MIĘDZY WYMIARAMI WIĘZI MATKI Z DZIECKIEM A JEJ SATYSFAKCJĄ Z ŻYCIA}

Kolejne z prezentowanych analiz dotyczą określenia roli prężności jako mediatora między wymiarami więzi z dzieckiem a satysfakcją z życia młodych matek. W pierwszej kolejności należało sprawdzić istotność związków między:

A. Wymiarami więzi z dzieckiem (jakość więzi, brak wrogości wobec dziecka, przyjemność w kontakcie $\mathrm{z}$ dzieckiem) a prężnością.

B. Prężnością a satysfakcją z życia.

C. Wymiarami więzi z dzieckiem (jakość więzi, brak wrogości względem dziecka, przyjemność w kontakcie z dzieckiem) a satysfakcją z życia.
D. Rozpoznanie istotności powyższych związków pozwoli włączyć prężność do analizy związku między więzią z dzieckiem a satysfakcją z życia młodych matek. Jeśli w tym układzie zmienna prężność wykaże istotny spadek wskaźnika beta dla obliczonego związku między wymiarami więzi i satysfakcją z życia, to możemy mówić o jej mediującym charakterze (C'; rysunek 1).

Ze względu na uzyskane wyniki prezentowane $\mathrm{w}$ powyższych tabelach prężność jako mediator będzie analizowana w związku między każdym wymiarem więzi matki z dzieckiem a satysfakcją z życia. Wykonano analizę mediacji zgodnie $z$ podejściem zaproponowanym przez Barona i Kenny'ego (1986) oraz uzupełnioną o test Sobela (1982).

\section{PRĘŻNOŚĆ JAKO MEDIATOR JAKOŚCI WIĘZI MATKI Z DZIECKIEM A JEJ SATYSFAKCJĄ Z ŻYCIA}

W pierwszym etapie analiz mediacyjnych jako zmienną niezależną przyjęto jakość więzi z dzieckiem, jako mediatora - prężność oraz jako zmienną zależną - satysfakcję z życia. Potwierdzono bezpośredni związek między zmienną niezależną - jakością więzi a mediatorem prężnością (A). Zgodnie z przewidywaniami im

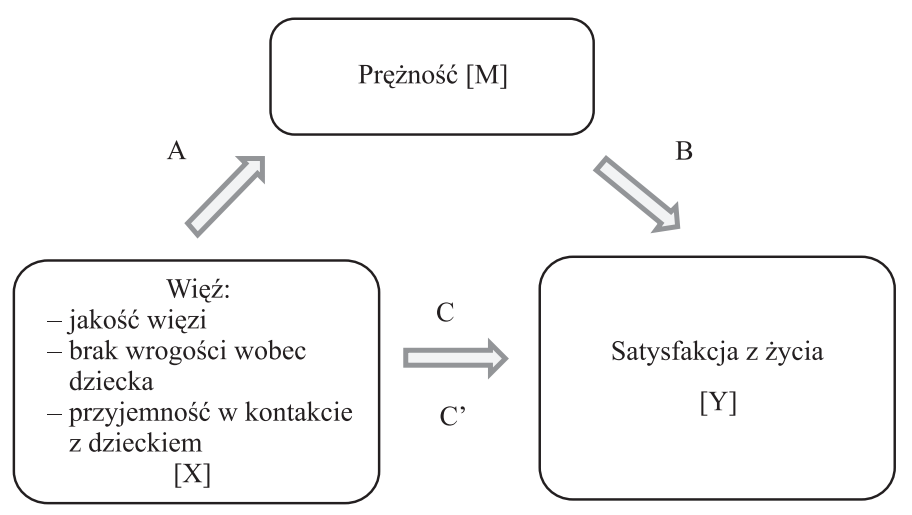

Rysunek 1. Schemat testowanych zależności między zmienną niezależną (wymiary więzi z dzieckiem) a zmienną zależną (satysfakcja z życia) za pośrednictwem zmiennej pośredniczącej (prężność) - poszukiwanego mediatora związku między zmienną $\mathrm{X}$ a zmienną $\mathrm{Y}$

Źródło: opracowanie własne na podstawie modelu Barona i Kenny’ego (1986). 
wyższe było natężenie więzi matki z dzieckiem, tym wyższym poziomem prężności charakteryzowała się matka $(\beta=.51 ; p<.001)$. Testowany model regresji okazał się dobrze dopasowany do danych $F(1.294)=101.28 ; p<.001 ; R^{2}=.26$.

W drugim etapie analizy sprawdzono istotność związku między mediatorem (prężność) a zmienną zależną (satysfakcja z życia, B). Ponownie relacja okazała się istotna: im wyższy był poziom prężności kobiet, tym wyższy był również poziom ogólnej satysfakcji z życia $(\beta=.58 ; p<.001)$ - model był dobrze dopasowany do danych $F(1.338)=172.54 ; p<.001$; $R^{2}=.34$.

Trzeci krok analizy mediacyjnej polegał na określeniu związku między zmienną niezależną (jakością więzi) a zmienną zależną (satysfakcja z życia, C). Okazało się, że im wyżej matki oceniały swoją więź z dzieckiem, tym wyższa była ich satysfakcja z życia $(\beta=.43$; $p<.001)$. Testowany model regresji okazał się dobrze dopasowany do danych $F(1.294)=$ $66.22 ; p<.001 ; R^{2}=.18$.

Ostatecznie gdy w testowanym modelu uwzględniono zarówno zmienną niezależną jak i mediatora, rola zmiennej niezależnej w przewidywaniu uległa osłabieniu $(\beta=.19 ; p<.001)$, podczas gdy mediator pozostał $w$ istotnej relacji ze zmienną zależną $(\beta=.47 ; p<.001) F(2.293)$ $=77.98 ; p<.001, R^{2}=0.35$. Test Sobela wy- niósł $3.65 ; p<0.001$. Mamy tutaj do czynienia z częściową mediacją prężności, gdyż test Sobela jest istotny statystycznie, a wartość $\beta$ w regresji zmiennej niezależnej na zależną przy udziale mediatora ulega osłabieniu $(\beta=.43 \geq$ $\beta=.19)$ Można więc wywnioskować, że prężność jest istotnym mediatorem związku jakości więzi matki z dzieckiem a jej satysfakcją z życia: im wyżej ocenia się jakość więzi matki z dzieckiem, tym wyższy jest poziom jej satysfakcji z życia, przy udziale wysokiej prężności (rysunek 2).

\section{PRĘŻNOŚĆ JAKO MEDIATOR MIĘDZY BRAKIEM WROGOŚCI WZGLĘDEM DZIECKA A SATYSFAKCJĄ Z ŻYCIA MATKI}

W początkowym etapie analiz mediacyjnych jako zmienną niezależną przyjęto brak wrogości wobec dziecka, jako mediator - prężność oraz jako zmienną zależną - satysfakcję z życia. Potwierdzono bezpośredni związek między zmienną niezależną - brakiem wrogości względem dziecka a mediatorem - prężnością (A). Zgodnie z przewidywaniami im mniej wrogości przejawiały matki względem dziecka, tym wyższym poziomem prężności się charakteryzowały $(\beta=.40 ; p<.001)$. Testowany

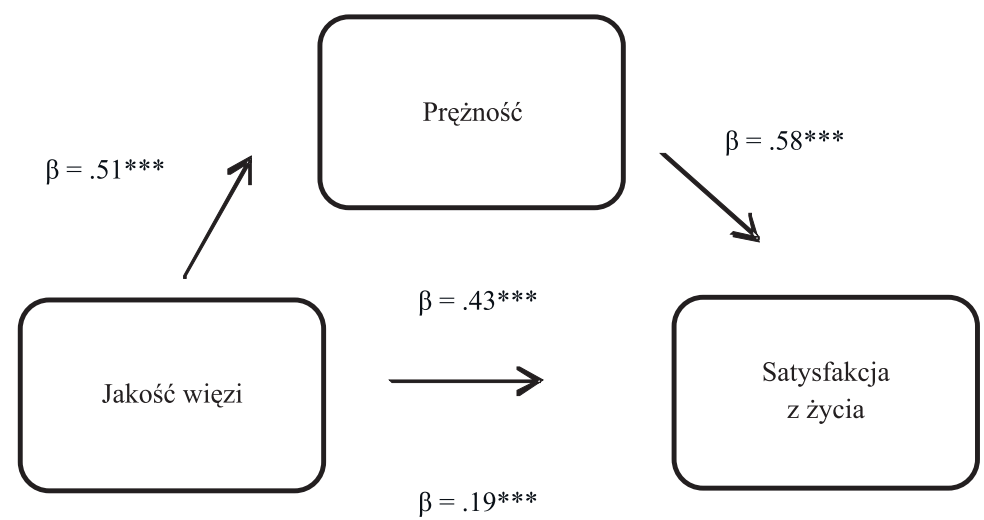

Rysunek 2. Schemat mediacyjnej roli prężności pomiędzy jakością więzi matki z dzieckiem a jej satysfakcją z życia $(* * * p<.001)$

Źródło: opracowanie własne. 
model regresji okazał się dobrze dopasowany do danych $F(1.294)=57.01 ; p<.001 ; R^{2}=.16$.

Następnie sprawdzono istotność związku między mediatorem (prężność) a zmienną zależną (satysfakcja z życia, B). Ponownie relacja okazała się istotna: im wyższy był poziom prężności kobiet, tym wyższy był również poziom ogólnej satysfakcji z życia $(\beta=.58$; $p<.001)-$ model był dobrze dopasowany do danych $F(1.338)=172.54 ; p<.001 ; R^{2}=.34$.

Kolejny etap analizy mediacyjnej polegał na określeniu związku między zmienną niezależną (brak wrogości wobec dziecka) a zmienną zależną (satysfakcja z życia, C). Okazało się, że im mniej było wrogości w relacji matkadziecko, tym większa była satysfakcja z życia matek $(\beta=41 ; p<.001)$. Testowany model regresji okazał się dobrze dopasowany do danych $F(1.294)=41.85 ; p<.001 ; R^{2}=.17$. Należy podkreślić, iż pomimo uzyskanych istotnych wyników w analizie regresji współczynniki $R^{2}$ są stosunkowo niskie.

Ostatecznie gdy w testowanym modelu uwzględniono zarówno zmienną niezależną, jak i mediatora, rola zmiennej niezależnej w przewidywaniu uległa osłabieniu $(\beta=.22 ; p<.001)$, podczas gdy mediator pozostał $\mathrm{w}$ istotnej relacji ze zmienną zależną $(\beta=.48 ; p<.001) F(2.293)$ $=82.48 ; p<.001, R^{2}=.36$. Test Sobela wyniósł $7.00(p<.001)$. Ponownie mamy tutaj do czynienia z częściową mediacją prężności, gdyż test Sobela jest istotny statystycznie, a wartość $\beta$ w regresji zmiennej niezależnej na zależną przy udziale mediatora ulega osłabieniu $(\beta=.41 \geq$ $\beta=.22)$. Można więc wywnioskować, że prężność jest istotnym mediatorem związku braku wrogości względem dziecka a satysfakcją z życia matki: im mniej wrogości w relacji matkadziecko, tym wyższy jest poziom satysfakcji z życia matki przy udziale wysokiej prężności (rysunek 3).

\section{PRĘŻNOŚĆ JAKO MEDIATOR PRZYJEMNOŚCI W KONTAKCIE Z DZIECKIEM A SATYSFAKCJA Z ŻYCIA}

W pierwszym etapie analiz mediacyjnych jako zmienną niezależną przyjęto przyjemność w kontakcie $\mathrm{z}$ dzieckiem, jako mediatora - prężność oraz jako zmienną zależną - satysfakcję z życia. Potwierdzono bezpośredni związek między zmienną niezależną - przyjemnością w kontakcie $\mathrm{z}$ dzieckiem a mediatorem - prężnością (A). Zgodnie z przewidywaniami im wyższy był poziom przyjemności w kontakcie matki z dzieckiem, tym wyższym poziomem prężności matki się charakteryzowały $(\beta=.38 ; p<.001)$. Testowany model regresji okazał się dobrze dopasowany do danych $F(1.294)=50.07 ; p<.001 ; R^{2}=.15$.

$\mathrm{W}$ drugim etapie analizy sprawdzono istotność związku między mediatorem (prężnością)

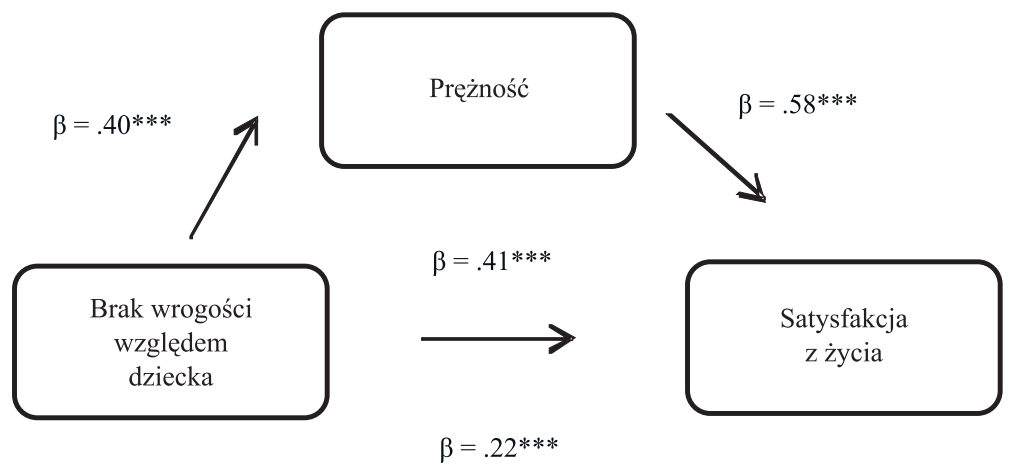

Rysunek 3. Schemat mediacyjnej roli prężności pomiędzy jakością więzi z dzieckiem (brak wrogości względem dziecka) a satysfakcją z życia $(* * * p<.001)$

Źródło: Opracowanie własne. 
a zmienną zależną (satysfakcja z życia, B). Ponownie relacja okazała się istotna: im wyższy był poziom prężności kobiet, tym wyższy był również poziom ich ogólnej satysfakcji z życia $(\beta=.58 ; p<.001)$ - model był dobrze dopasowany do danych $F(1.338)=172.54 p<.001$; $R^{2}=.34$.

Trzeci etap analizy mediacyjnej polegał na określeniu związku między zmienną niezależną (przyjemność w kontakcie z dzieckiem) a zmienną zależną (satysfakcja z życia, C). Okazało się, że im wyższy był poziom przyjemności matki w kontakcie $\mathrm{z}$ dzieckiem, tym wyższa była ich satysfakcja z życia $(\beta=.23 ; p<.001)$. Testowany model regresji okazał się dobrze dopasowany do danych $F(1.294)=16.33 ; p<.001 ; R^{2}=.05$. W tym przypadku należy również podkreślić, iż pomimo uzyskanych istotnych wyników w analizie regresji otrzymywane współczynniki $R^{2}$ są stosunkowo niskie.

Ostatecznie gdy w testowanym modelu uwzględniono zarówno zmienną niezależną, jak i mediatora, rola zmiennej niezależnej w przewidywaniu zmiennej zależnej stała się nieistotna statystycznie $(\beta=.02 ; n . i$.), podczas gdy mediator pozostał $\mathrm{w}$ istotnej relacji ze zmienna zależną $(\beta=.56 ; p<.001) F(2.293)=69.05$; $p<.001, R^{2}=.32$. Test Sobela wyniósł 6.73 $(p<.001)$. Mamy tutaj do czynienia z całkowita mediacją prężności, gdyż test Sobela jest istotny statystycznie, a wartość $\beta$ w regresji zmiennej niezależnej na zależną przy udziale mediatora przestaje istotnie przewidywać zmienną zależna $(\beta=.23 \geq \beta=.02 ; n . i$.). Można więc wnioskować, że prężność jest istotnym mediatorem związku przyjemności $\mathrm{w}$ kontakcie $\mathrm{z}$ dzieckiem a satysfakcją z życia matki: im wyższy jest poziom przyjemności matki w kontakcie z dzieckiem, tym wyższy jest poziom ich satysfakcji z życia przy udziale wysokiej prężności (rysunek 4).

\section{DYSKUSJA}

Zrealizowane badania pozwoliły na potwierdzenie zależności pomiędzy poszczególnymi wymiarami prężności, więzi z dzieckiem a satysfakcją z życia młodych matek. Zarówno prężność, jak i wszystkie wymiary więzi z dzieckiem okazały się istotnie znaczące dla satysfakcji z życia kobiet wchodzących w rolę matki. Zgodnie z założeniami zainspirowanymi analizą literatury przedmiotu młode kobiety, które charakteryzują się wysoką prężnością i wysoką jakością więzi z dzieckiem, są najbardziej usatysfakcjonowane z własnego życia. Jednocześnie prężność okazała się odgrywać rolę mediatora pomiędzy więzią z dzieckiem na wszystkich jej wymiarach a poczuciem satysfakcji z życia. Można zatem wnioskować, że prężność pełni funkcję ochronną wobec trudności, z jakimi matka musi mierzyć się

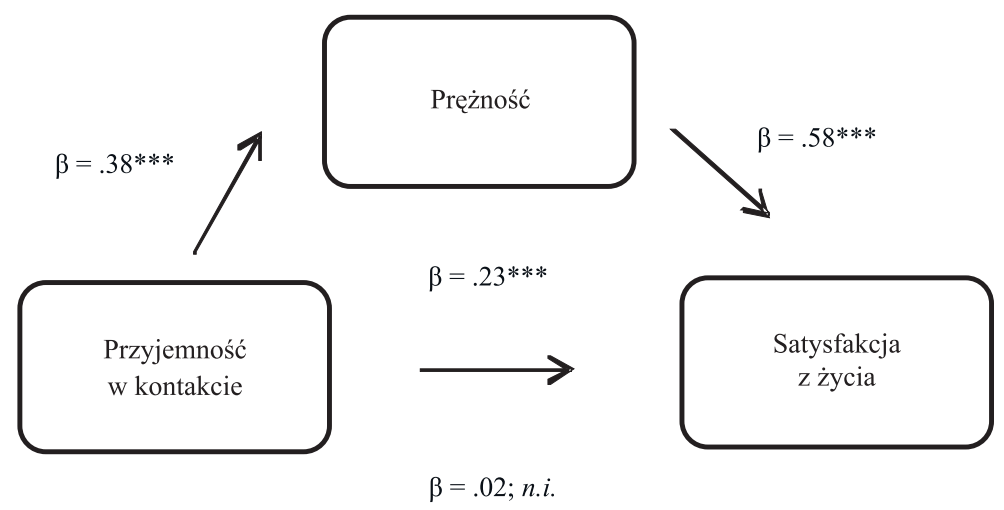

Rysunek 4. Schemat mediacyjnej roli prężności pomiędzy przyjemnością w kontakcie z dzieckiem a satysfakcją z życia matki $(* * * p<.001 ; n . i .-$ nieistotne statystycznie)

Źródło: opracowanie własne. 
w obliczu pojawienia się dziecka. Poczucie braku satysfakcji związane z koniecznością wejścia w nową rolę - rolę matki - i tym samym konieczność rezygnacji z innych obszarów aktywności może być kompensowana czynnikiem sprzyjającym dobremu radzeniu sobie, czyli prężnością. Zrealizowane badania, poparte założeniami teoretycznymi, dowiodły znamiennego znaczenia prężności nie tylko wtedy, kiedy rodzina musi zmierzyć się z trudnościami natury zdrowotnej, ale także w relacjach zwykłych, zdrowych rodzin, które nie doświadczyły poważnych kryzysów. Uzyskane rezultaty korespondują z wynikami badań opisanymi w literaturze przedmiotu wskazującymi na znaczenie prężności jako czynnika buforującego wpływ negatywnych oddziaływań na dobrostan jednostki (Ogińska-Bulik, 2014; Simer, 2006). Przyjęty model teoretyczny zakłada mediującą rolę prężności jako czynnika oddziałującego na relację pomiędzy więzią z dzieckiem a satysfakcją z życia. Nie można jednak wykluczyć, przyjmując procesualną definicję prężności (Charney, 2004; Connor, 2006; Hjemdal, 2007; Pooley, Cohen, Connor, 2010), że to prężność zwrotnie oddziałuje również na jakość więzi z dzieckiem.

W dalszych analizach warto uwzględnić liczbę dzieci w rodzinie. Można bowiem założyć, że matki z kilkorgiem dzieci, po doświadczeniu wcześniejszego macierzyństwa, mają z tej racji wyższy poziom prężności, co może być wynikiem hartowania. Model warto także uzupełnić o perspektywę ojca oraz przyjrzeć się rodzinom niepełnym i zadać sobie pytanie: czy w rodzinach niepełnych lub patchworkowych relacja pomiędzy więzią z dzieckiem a satysfakcją z życia i prężnością jest podobna czy też inna.

Prezentowane badania, pomimo istotnych walorów naukowych, mają również pewne ograniczenia. Jedno z nich dotyczy ograniczonej możliwości generalizowania wyników badań na całą populację. O zawężonej możliwości generalizowania wyników przesądza między innymi celowy dobór osób do grupy badanej: były to osoby znajdujące się w okresie wczesnej dorosłości. Przeprowadzenie badań w lepiej ustrukturyzowanej grupie, uwzględniającej większą liczbę osób w różnych okresach rozwojowych, mogłoby dostarczyć bardziej precyzyjnych informacji na temat badanych zależności.

Prezentowane badania w dużej mierze zostały zrealizowane w schemacie korelacyjnym. Pozwoliło to na wykrycie istotnych związków między analizowanymi zmiennymi oraz predykcję jednej zmiennej na podstawie drugiej. Badania korelacyjne uniemożliwiają jednak wnioskowanie przyczynowo-skutkowe (Sierau, Herzberg, 2012). Przedstawione wyniki badań nie wyczerpują problematyki związanej z satysfakcją czerpaną z macierzyństwa. Mogą jednak stanowić punkt wyjścia do kolejnych pytań i dalszej eksploracji w zakresie jakości życia rodzinnego. Bardzo cenne byłoby przeprowadzenie w przyszłości badań, które wskazałyby strukturę zależności przyczynowych i wpływ określonych zmiennych na jakość funkcjonowania młodych matek - ich prężność i satysfakcję z życia.

W przyszłych badaniach do obszaru eksploracji warto byłoby włączyć również inne zmienne, które mogą się okazać istotne z punktu widzenia jakości macierzyństwa i jej znaczenia dla ogólnie pojętej jakości życia. Literatura przedmiotu wskazuje bowiem, że w ocenie życiowej satysfakcji znaczącą rolę odgrywa zadowolenie $\mathrm{z}$ relacji partnerskich (Doroszewicz, 2008; Fincham, 2008), ale także pełnienie funkcji rodzicielskich (Bakiera, 2013), sposób radzenia sobie ze stresem, kontrola emocji (Półtorak, 2013), wsparcie społeczne (Cutrona, 1996; Cutrona, Sheffer, Wesner, Gardner, 2007; Dehle, Landers, 2005) oraz styl przywiązania (Bartholomew, Horowitz, 1991; Hazan, Shaver, 1987; Plopa, 2005).

W dziedzinie poszukiwań wyznaczników funkcjonowania młodych matek w dynamicznie zmieniającym się świecie należałoby także uwzględnić uwarunkowania środowiskowe, istotne z punktu widzenia jakości macierzyństwa i odczuwanej z niego satysfakcji, takie jak: sytuacja mieszkaniowa, wsparcie finansowe, podział obowiązków domowych i sposób ich realizacji, gdyż - jak wskazuje literatura - są to czynniki potencjalnie konfliktogenne, które mogą modyfikować relacje partnerów i jakość ich funkcjonowania (Brannon, 2002). 


\section{WNIOSKI}

Prezentowane badania miały na celu zanalizowanie, czy prężność wiąże się z poszczególnymi wymiarami więzi z dzieckiem, tj. jakością więzi, brakiem wrogości wobec dziecka, przyjemnością w kontakcie z dzieckiem oraz z satysfakcją z życia młodych matek. Dodatkowo za cel obrano przeanalizowanie mediującej roli prężności w związku pomiędzy ocenąjakości więzi matki z dzieckiem a poczuciem satysfakcji z życia. Wszystkie przyjęte hipotezy badawcze uzyskały potwierdzenie. Okazało się, że występują istotne korelacje między poszczególnymi wymiarami więzi z dzieckiem a satysfakcją z życia młodych matek, między poziomem ich prężności a satysfakcją z życia oraz między poziomem prężności matek a oceną jakości tworzonej więzi z dzieckiem. Im wyższa była ocena więzi matki z dzieckiem (wyższa ocena jakości więzi, brak wrogo- ści wobec dziecka, przyjemność w kontakcie z dzieckiem), tym wyżej kobiety oceniały własną satysfakcję z życia. Wykazano również znaczenie prężności zarówno dla satysfakcji z życia młodych matek, jak i dla ich oceny więzi z dzieckiem. Okazało się bowiem, że im wyższy poziom prężności cechował kobiety, tym wyższy był poziom ich satysfakcji oraz bardziej pozytywna ocena więzi emocjonalnej łączącej matkę i dziecko (wyższa ocena jakości więzi, brak wrogości wobec dziecka, przyjemność w kontakcie z dzieckiem). Ponadto po przeprowadzeniu analizy regresji wykazano, że prężność pełni funkcję pośrednicząca w relacji między jakością więzi z dzieckiem a satysfakcją z życia matek. Okazało się, że im wyższa jest jakość więzi oraz wyższy poziom przyjemności w kontakcie z dzieckiem i mniej nasilona wrogość matki względem dziecka, tym wyższy jest poziom ich satysfakcji z życia przy udziale wysokiej prężności.

\section{BIBLIOGRAFIA}

Bakiera L. (2013), Zaangażowane rodzicielstwo a autokreacyjny aspekt rozwoju dorostych. Warszawa: Wydawnictwo Difin.

Baron R.M., Kenny D.A. (1986), The moderator-mediator variable distinction in social psychological research: conceptual, strategic, and statistical considerations. Journal of Personality and Social Psychology, 51(6), $1173-1182$.

Bartholomew K., Horowitz L.M. (1991), Attachment styles among young adults: A test of four-category model. Journal of Personality and Social Psychology, 61(2), 226-244.

Bielawska-Batorowicz E. (2006), Psychologiczne aspekty prokreacji. Katowice: Wydawnictwo Śląsk.

Bird C. (1997), Gender differences in the social and economic burdens of parenting and psychological distress. Journal of Marriage and the Family, 59, 809-823.

Brannon L. (2002), Psychologia rodzaju. Gdańsk: Gdańskie Wydawnictwo Psychologiczne.

Braun-Gałkowska M. (1992), Psychologiczna analiza systemów rodzinnych osób zadowolonych i niezadowolonych z matzeństwa. Lublin: Towarzystwo Naukowe Katolickiego Uniwersytetu Lubelskiego.

Charney D.S. (2004), Psychological mechanisms id resilience and vulnerability. Implications for successful adaptation to extreme stress. American Journal of Psychiatry, 161, 195-216.

Condon J.T. (1993), The assessment of antenatal emotional attachment: Development of a questionnaire instrument. British Journal of Medical Psychology, 66(2), 167-183.

Condon J.T, Corkindale C. (1998), The assessment of parent-to-infant attachment: Development of a self-report questionnaire instrument. Journal of Reproductive and Infant Psychology, 16(1), 57-76.

Connor K.M. (2006), Assessment of resilience in the aftermath of trauma. Journal of Clinical Psychiatry, 67(2), 46-49.

Cutrona C.E. (1996), Social Support in Couples. Thousand Oaks, CA: Sage.

Cutrona C.E., Shaffer P.A., Wesner K.A., Gardner K.A. (2007), Optimally matching support and perceived spousal sensitivity. Journal of Family Psychology, 21, 754-758. 
Dehle C., Landers J.E. (2005), You can't always get what you want, but can you get what you need? Personality traits and social support in marriage. Journal of Social and Clinical Psychology, 24(7), 1051-1076.

Diener E., Emmons R.A., Larsen R.J., Griffin S. (1985), The Satisfaction With Life Scale. Journal of Personality Assessment, 49(1), 71-75.

Doroszewicz K. (2008), Bliskie związki a jakość życia. Psychologia Jakości Życia, 7(1,2), 5-18.

Evenson R.J., Simon R.W. (2005), Clarifying the relationship between parenthood and depression. Journal of Health and Social Behaviour, 46(4), 341-358.

Fincham F.D. (2008), Marital happiness. The Encyclopedia of Positive Psychology. NewYork: John Wiley.

Hazan C., Shaver P. (1987), Romantic love conceptualized as an attachment process. Journal of Personality and Social Psychology, 52, 511-524.

Hess C.R., Papas M.A., Black M.M. (2002), Resilience among African American adolescent mothers: Predictors of positive parenting in early infancy. Journal of Pediatric Psychology, 27(7), 619-629.

Heszen I., Sęk, H. (2007), Psychologia zdrowia. Warszawa: Wydawnictwo Naukowe PWN.

Hjemdal O. (2007), Measuring protective factors: The development of two resilience scales in Norway. Child and adolescence Psychiatric Clinics of North America, 16, 303-321.

Horton T.V., Wallander J.L. (2001), Hope and social support as resilience factors against psychological distress of mothers who care for children with chronic physical conditions. Rehabilitation Psychology, 46(4), 382-399.

International Test Commission (2005), International Guidelines on Computer-Based and Internet Delivered Testing, http://www.practest.com.pl/files/ITC-Stosowanie_test\%C3\%B3w.pdf (dostęp: 27 lutego 2019).

Juczyński Z. (2009), Narzędzia pomiaru w promocji i psychologii zdrowia. Warszawa: Pracownia Testów Psychologicznych.

Malina A. (2014), Wczesna dorostość w cyklu życia człowieka. Wspótczesne problemy z realizacja zadań rozwojowych młodych dorostych. Bydgoszcz: Wydawnictwo UKW.

Malina A., Pooley J.A., Harms C. (2016), Skala Osobistej Adaptacyjności - polska adaptacja Lifespan Individual Resilience Scale. Przeglad Psychologiczny, 59(4), 435-450.

Mercer R.T., Ferketisch S.L. (1990), Predictors of parental attachment during early parenthood. Journal of Advanced Nursing, 15, 268-280.

Mercer R.T., Ferketich S., May K., De Joseph J., Sollid D. (1988), Further exploration of maternal and paternal fetal attachment. Research in Nursing and Health, 11(2), 83-95

https://doi.org/10.1002/nur.4770110204

Nomaguchi K. (2012), Parenthood and psychological well-being: Clarifying the role of child age and parent-child relationship quality. Social Science Research, 41(2), 489-498.

Ogińska-Bulik N. (2014), Prężność psychiczna a zadowolenie z życia osób uzależnionych od alkoholu. Alocholism and Drug Addiction, 27(4), 319-324.

Ogińska-Bulik N., Juczyński Z. (2008), Osobowość. Stres a zdrowie. Warszawa: Wydawnictwo Difin.

Pawlicka P., Chrzan-Dętkoś M., Lutkiewicz K. (2013), Prężność psychiczna przyszłych matek oraz kolejność budowania więzi z nienarodzonym jeszcze dzieckiem. Family Forum, 3, 139-152.

Plopa M. (2005), Więzi w matżeństwie i rodzinie-metody badań. Kraków: Wydawnictwo „Impuls”.

Półtorak M. (2013), Psychiczne mechanizmy odczuwanego stresu i zadowolenia partnerów ze związku w okresie przyjścia na świat pierwszego dziecka. Niepublikowana praca doktorska.

Pooley J.A., Cohen L. (2010), Resilience: A definition in context. The Australian Community Psychologist, 22(1), 30-37.

Pooley J.A., Cohen L. O'Connor M. (2010), Community Resilience: A Study of Communities Facing Impending Natural Disasters. Berlin: Lambert Academic Publishing.

Simer N. (2006), Personality, stress and coping. W: M. Vollrath (red.) Handbook of Personality and Health (s. 73-113). Chichester: Wiley.

Shin H., Lee J.H. (2008), A Correlation Study on the Resilience of Children with Cancer and Their Mothers. Journal of Korean Oncology Nursing, 8(1), 24-31.

Sierau S., Herzberg P.Y. (2012), Conflict resolution as a dyadic mediator: Considering the partner perspective on conflict resolution. European Journal of Personality, 26, 221-232. 
Sobel M.E. (1982), Asymptotic confidence intervals for indirect effects in structural equation models. W: S. Leinhart (red.), Sociological Methodology (s. 290-312). San Francisco: Jossey-Bass.

Szafraniec K. (2011), Młodzi 2011. Warszawa: Kancelaria Prezesa Rady Ministrów.

Umberson D., Pudrovska T., Reczek C. (2010), Parenthood, Childlessness, and Well-Being: A Life Course Perspective. Journal of Marriage and Family, 72(3), 612-629.

Wojciszke B. (2004), Psychologia miłości. Intymność. Namiętność. Zaangażowanie. Gdańsk: Gdańskie Wydawnictwo Psychologiczne. 